Paleozoic and Mesozoic stratigraphy of the northern part of the Ruby Range, southwestern Montana

GEOLOGICAL SURVEY BULLETIN 1405 -I 
II

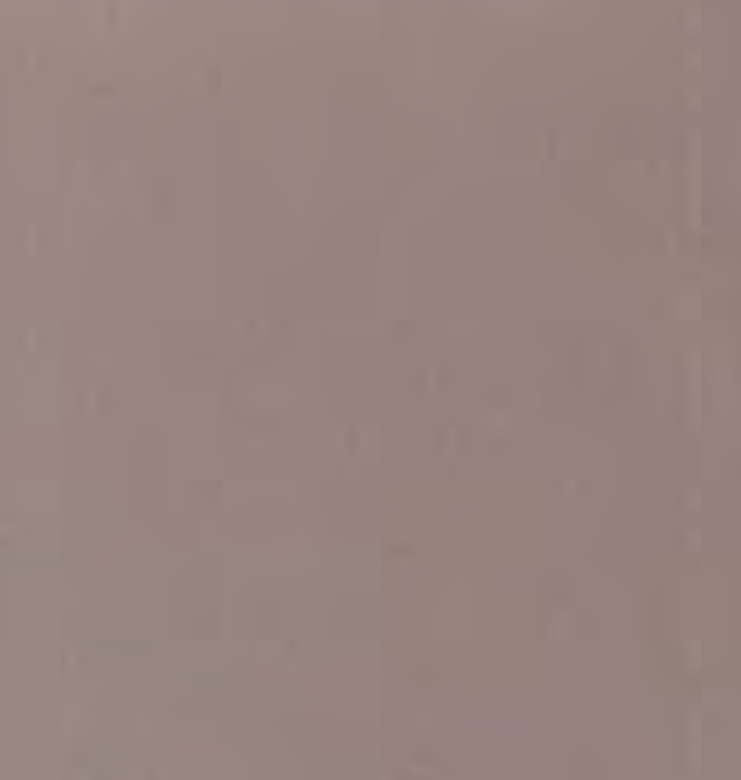

(1)

Initit.

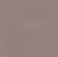

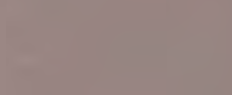

w.

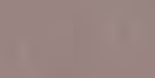

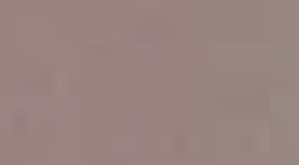

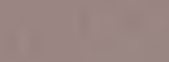

14

(11:

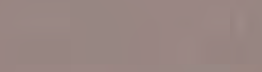

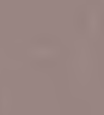

if

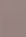

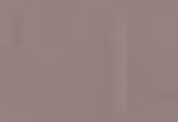

te

(1)
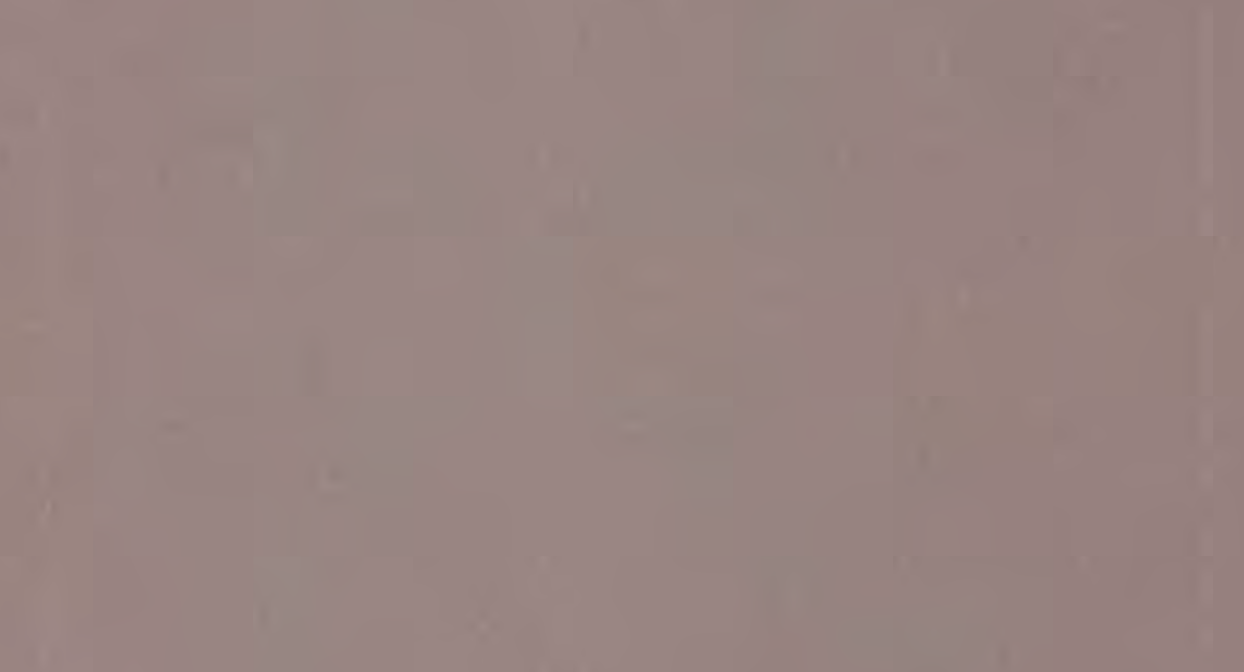

$1+x+2 x$

antily

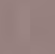

r.

a

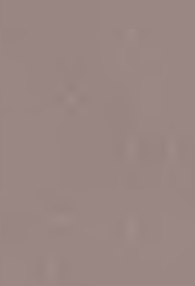

I

11

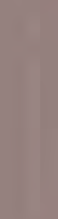

11 


\section{Paleozoic and Mesozoic}

stratigraphy of the northern part of the Ruby Range, southwestern Montana

By RUSSELL G. TYSDAL

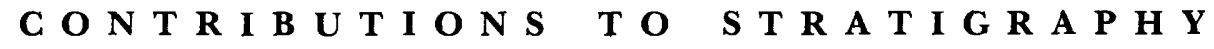

G E O L O G I C A L S URVEY B ULLETIN 1405 -I

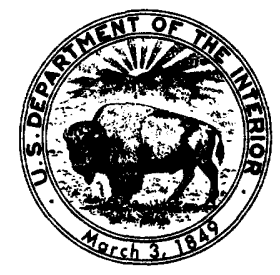




\section{UNITED STATES DEPARTMENT OF THE INTERIOR}

THOMAS S. KLEPPE, Secretary

\section{GEOLOGICAL SURVEY}

V. E. McKelvey, Director

Library of Congress Cataloging in Publication Data

Tysdal, Russel G.

Paleozoic and Mesozoic stratigraphy of the northern part of the Ruby Range, southwestern Montana. (Contributions to stratigraphy)

(Geological Survey Bulletin 1405-I)

Bibliography.

Supt. of Docs. no.: I 19.3:1405-I.

1. Geology, Stratigraphic-Paleozoic. 2. Geology, Stratigraphic-Mesozoic. 3. GeologyMontana-Ruby Mountains. I. Title. II. Series. III. Series: United States Geological Survey Bulletin 1405-I..

QE75.B9 no. 1405-I[QE654] 557.3'08s [557.86'663] 76-608035

For sale by the Superintendent of Documents, U. S. Government Printing Office Washington, D. C. 20402

Stock Number 024-001-02854-9 


\section{CONTENTS}

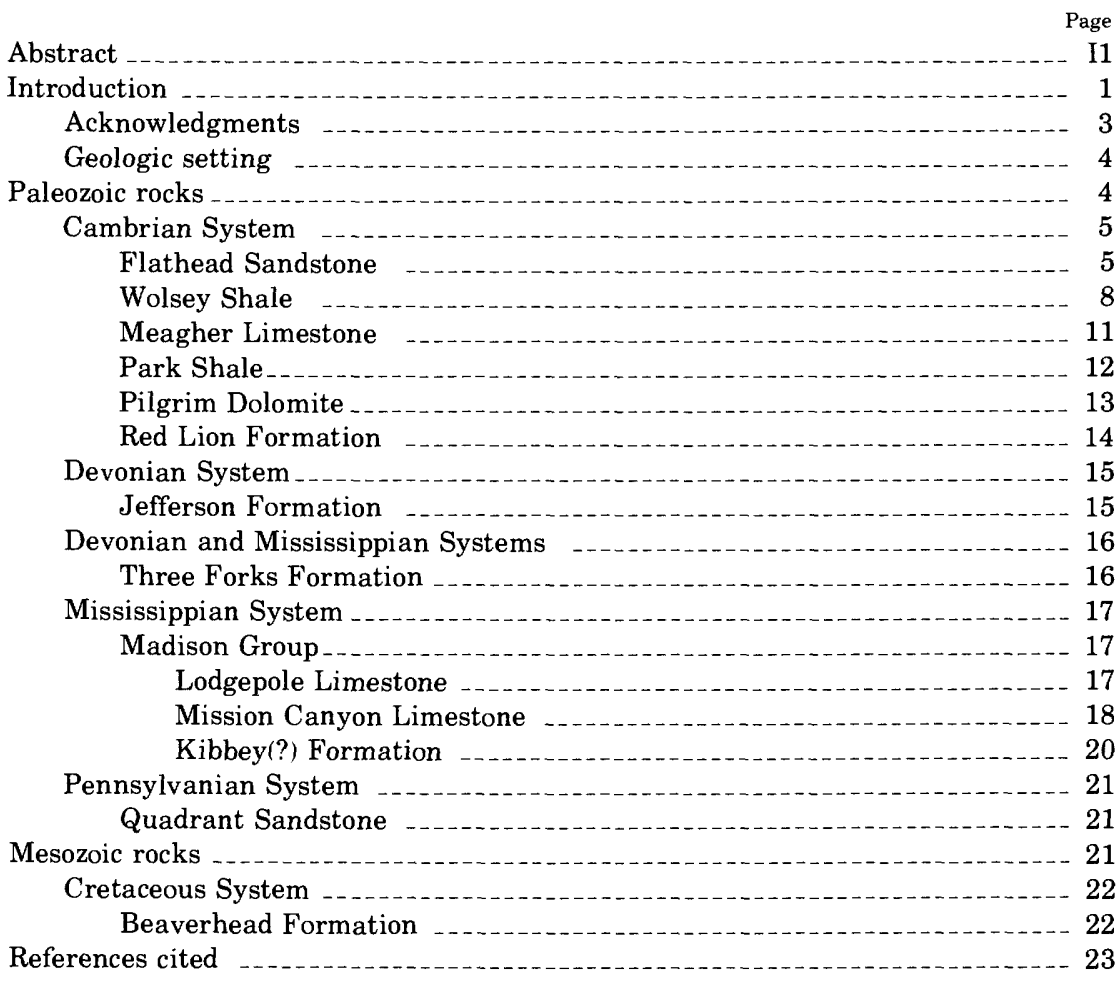

\section{ILLUSTRATIONS}

Figure 1. Sketch map of southwestern Montana showing area of report and

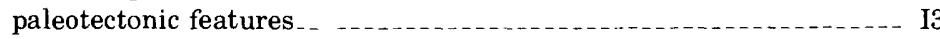

2. Generalized columnar section of Paleozoic and Mesozoic rocks in north-

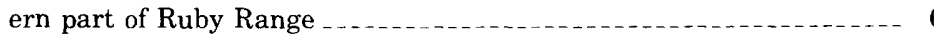

3. Generalized stratigraphic cross section of Paleozoic rocks in northern

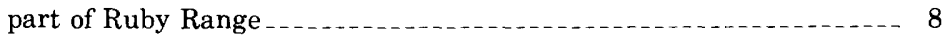

4. Correlation chart for Middle and Upper Cambrian rocks in Montana_. 10 


\section{CONTENTS}

\section{TABLE}

TABLE 1. Stratigraphic position of fossils collected from Mississippian Lodgepole

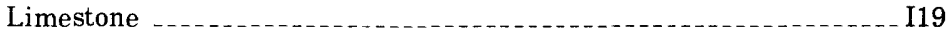




\title{
PALEOZOIC AND MESOZOIC STRATIGRAPHY OF THE NORTHERN PART OF THE RUBY RANGE, SOUTHWESTERN MONTANA
}

\author{
By Resseli. G. Tismal.
}

\section{ABSTRACI}

The northern third of the Ruby Range, southwestern Montana, contains about 5,000 feet $(1,525 \mathrm{~m})$ of Paleozoic marine sedimentary rocks overlying a basement of Precambrian metamorphic rocks. Mesozoic rocks are represented by a nonmarine conglomerate, the Beaverhead Formation.

The Cambrian sequence, composed largely of carbonate rocks, comprises the Flathead Sandstone at the base, Wolsey Shale, Meagher Limestone, Park Shale, Pilgrim Dolomite, and the Red Lion Formation. The Meagher Limestone is mainly dolomite in the southern part of the area, limestone in the northern part. The Pilgrim Dolomite is divisible into two main parts: cyclically interbedded dolomitic strata 2- to 10 -inch $(5-25 \mathrm{~cm})$ thick in the lower part, mainly dolomitic quartz sandstone and sandy dolomite in the upper part. The Red Lion Formation is composed mainly of dolomite; the upper third is dominated by bedded, dome-shaped, and columnar stromatolites.

The Devonian is represented by the Jefferson Formation, a dolomite unit containing several interstratified units of silty shale, and the lower part of the Three Forks Formation. The Three Forks is composed largely of clay shale but contains a prominent medial limestone unit. The upper (Mississippian) part of the Three Forks is overlain by three Mississippian formations. The Lodgepole Limestone is constituted of limy shale in the lower half and fossiliferous limestone in the upper half. It is overlain by the Mission Canyon Limestone, a formation that locally contains solution breccias and minor amounts of interbedded dolomite. The overlying red beds, made up of dolomite and sandstone, are questionably assigned to the Kibbey Formation. Pennsylvania rocks are represented by the Quadrant Sandstone, made up of interbedded limestone and sandstone in nearly equal amounts.

The Mesozoic is represented by a nonmarine conglomerate that is correlated with the Beaverhead Formation. It is composed of clasts derived from Paleozoic carbonate units and Precambrian (Belt Supergroup) quartzite.

\section{INTRODUCTION}

The Ruby Range is a north-trending block of mountains about $30 \mathrm{mi}(50 \mathrm{~km})$ long and $12 \mathrm{mi}(20 \mathrm{~km})$ wide, nearly surrounded by intermontane basins containing broad benchlands and alluvial sur- 
faces that slope gently away from the mountains. The mapped area makes up the northern third of the Ruby Range and the adjoining parts of the adjacent basins. The relief in the area ranges from about 5,000 feet $(1,525 \mathrm{~m})$ in the northernmost part of the area to 9,391 feet $(2,862 \mathrm{~m})$ atop Ruby Peak in the central part, a difference of 4,300 feet $(1,310 \mathrm{~m})$.

There is a close correspondence between topographic expression and lithology. The more rugged ridges are held up by Paleozoic carbonate rocks, the broad-backed and rounded ridges by Precambrian metamorphic rocks, and the benchlands and gently sloping surfaces by Cenozoic deposits.

The first geologic notation on the Ruby Range was recorded by a Hayden survey party that passed near the mountains in September 1871; they referred to the mountains as the Stinking Water Range (Hayden, 1872, p. 36-39, 143, 259-261). In 1902 and again in 1905 Earl Douglass collected Cambrian and Mississippian fossils from the northeastern part of the range (Douglass, 1905, 1909). Much later Hanson (1952) measured a Cambrian section near McHessor Creek; he used the section for regional correlation in southwestern Montana. A small Precambrian sedimentary iron-ore deposit in the southeastern part of the mapped area was studied by James and Wier (1972), and Tertiary rocks at the northern tip of the range were noted briefly in a report of Fields and Petkewich (1967).

Studies of the Ruby Range south of the area of this report include those of Klepper (1950), Dorr and Wheeler (1964), Wier (1965), and James, Wier, and Shaw (1969). Heinrich (1960) referred to many papers on the economic geology.

This report on the general stratigraphy of the Paleozoic and Mesozoic rocks of the northern part of the Ruby Range complements U.S. Geological Survey Miscellaneous Investigations Map I-951 (Tysdal, 1976). The map includes a brief description of the Precambrian metamorphic rocks underlying the sedimentary sequence and of the Tertiary rocks flanking the range. Detailed measured sections of the Paleozoic formations are given in an open-file report of the U.S. Geological Survey (Tysdal, 1970) that discusses and illustrates the carbonate petrology of some Cambrian units and presents a structural interpretation of the area.

The mapped area constitutes the mountainous parts of four $7 \frac{1}{2}$ quadrangles: Beaverhead Rock SE, Beaverhead Rock NE, Sheridan, and Laurin Canyon. It is delimited by $45^{\circ} 15^{\prime}$ to $45^{\circ} 24^{\prime} \mathrm{N}$. lat. and $112^{\circ} 07^{\prime} 30^{\prime \prime}$ to $112^{\circ} 22^{\prime} 30^{\prime \prime} \mathrm{W}$. long. (fig. 1 ).

The terms "thin-, medium-, and thick-bedded" as used throughout this report refer, respectively, to beds up to 6 in. $(15 \mathrm{~cm})$ thick, 6-18 in. $(15-45 \mathrm{~cm})$, and greater than $18 \mathrm{in} .(45 \mathrm{~cm})$ thick. "Massive" as 


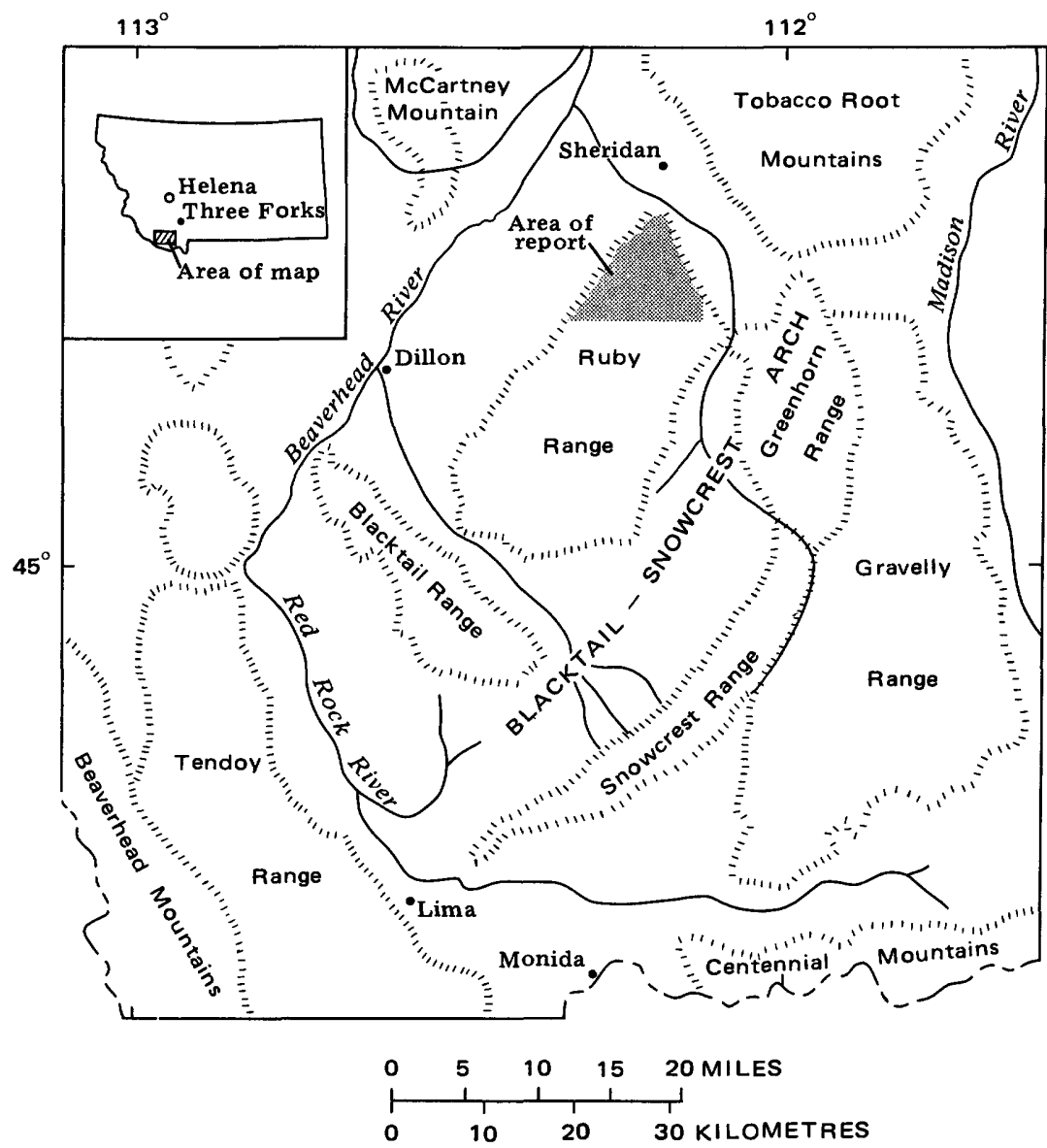

FIGURE 1.-Sketch map of southwestern Montana, showing area of report and paleotectonic features.

used here does not describe bedding thickness but rather describes the homogeneous weathering profile of a group of beds. Color terms used in the measured sections and in most of the text are from the "Rock Color Chart of the National Research Council" (Goddard and others, 1948).

\section{ACKNOWLEDGMENTS}

The north end of the Ruby Range was suggested as a study area by the late W. J. McMannis, of Montana State University, Bozeman. For stimulating discussions on the geology of the Ruby Range, I am indebted to J. A. Peterson and G. W. Crosby, both of the University of Montana, Missoula; E. T. Ruppel, of the U.S. Geological Survey; R. M. Petkewich, then a student at the University of Montana; and 
McMannis. I should like to thank Mr. and Mrs. George Knaggs of Sheridan, Mont., for their hospitality, and the ranchers of the area for their cooperation and helpfulness.

\section{GEOLOGIC SETTING}

The Ruby Range is one of several mountain ranges in southwestern Montana that contains a core of Precambrian metamorphic rock overlain by Paleozoic and younger sedimentary rocks. The range lies east of the Paleozoic hinge zone that separated the craton from the miogeosyncline to the west, and it is thought to be part of the nowsegmented Blacktail-Snowcrest arch (fig. 1), a large southwestplunging anticlinorium (Scholten, 1967). The range is broken by numerous so-called Laramide faults; its present block outline is the result of later Tertiary normal faulting. It is flanked by basins filled with Tertiary continental sedimentary rocks.

Precambrian metamorphic rocks, chiefly hornblende and biotite gneisses, the Dillon Granite Gneiss of Heinrich (1953), dolomitic marble, and numerous units of quartzo-feldspathic gneiss, are exposed mainly in the southern part of the mapped area. Sillimanite schist is present locally. Iron formation and associated quartzite and diopsidic gneiss are present in the southeastern part of the mapped area (James and Wier, 1972). Radiometric age determinations indicate that the last metamorphic event in the range took place about 1,600 m.y. ago (Giletti and Gast, 1961; Giletti, 1966, 1968). Detailed structural and petrographic studies of metamorphic rocks in the northern half of the Ruby Range were made by Heinrich (1960), James, Wier, and Shaw (1969), and Garihan (1973).

Tertiary rocks composed of dark-green-gray mudstone with interbedded poorly sorted locally conglomeratic siltstone and sandstone crop out at the northern tip of the range (Fields and Petkewich, 1967); these rocks have yielded late Eocene and Oligocene vertebrate fossils (Petkewich, 1972). A similar sequence of rocks occur along the western margin of the range. Miocene and Pliocene sedimentary rocks crop out locally in the basins beyond the margins of the range (Fields and Petkewich, 1967; Petkewich, 1972).

Quaternary deposits within the range are tufa, an unnamed conglomerate, alluvium, colluvium, landslides, and glacial deposits. The conglomerate, present on both the eastern and western flanks of the range, intertongues with tufa at one locality. Small basalt, andesite, and rhyolite intrusive bodies occur along some faults in the range.

\section{PALEOZOIC ROCKS}

Paleozoic rocks constitute most of the sedimentary sequence pre- 
served in the Ruby Range, aggregating a thickness of about $5,000 \mathrm{ft}$ $(1,640 \mathrm{~m})$. Cambrian rocks, which make up little more than a fifth of this sequence, were studied in greatest detail. Ordovician, Silurian, and Permian rocks are not present in the range, probably as a result of erosion rather than nondeposition. The sequence of rocks is shown in figure 2 .

The generalized stratigraphic relations derived from mapping and the stratigraphic position of the measured sections are shown schematically in figure 3. Detailed measured sections were published in an earlier report (Tysdal, 1970).

\section{CAMBRIAN SYSTEM}

\section{FLATHEAD SANDSTONE}

The oldest Paleozoic rocks in the area are those of the Flathead Sandstone of Middle Cambrian age (fig. 3, sections G and L). This formation, which unconformably overlies Precambrian metamorphic rocks, is well exposed only in cliff-forming outcrops and is commonly about $60 \mathrm{ft}(18 \mathrm{~m})$ thick. It consists mainly of light-brown to orange, fine- to medium-grained quartz sandstone in beds $1-2 \mathrm{ft}(30-60 \mathrm{~cm})$ thick. The basal part of the formation includes lenses of subangular to subrounded granules and pebbles of quartz in a coarse-grained sand matrix; similar lenses are present locally in the upper part of the formation. Pebbles of clay shale to $3 \mathrm{~cm}$ long and a few millimetres thick and locally surrounded by coarse grains of sand were observed at the top of the Flathead in the rocks about $1 \frac{112}{\mathrm{mi}}(3 \mathrm{~km})$ southwest of Section J (fig. 3) in $\mathrm{SE}^{1 / 4} \mathrm{NW}^{1 / 1} / 4$ sec. 2, T. 7 S., R. $6 \mathrm{~W}$. (Beaverhead Rock SE quadrangle).

Examination in thin section shows that the Flathead Sandstone is more than 98 percent quartz with minor amounts of chert, mica, hematite, limonite, heavy minerals, metamorphic rock fragments, and wisps of clay. Glauconite occurs locally in the uppermost part of the formation. The sandstone is mostly moderately to well sorted; the moderately sorted sands are bimodal and consist of coarse sand interlaminated with fine- to medium-grained sand. Most quartz grains are subrounded to rounded (3.5 to 5, classification of Powers, 1953) and are cemented by optically continuous overgrowths. Abundant double overgrowths and one grain with a triple overgrowth were seen in a thin section from one locality (about $1 \frac{1 / 2}{\mathrm{mi}}(2.5 \mathrm{~km})$ west-southwest of section J), suggesting that some of the sand is recycled from older sandstone.

The parts of the shale section that are exposed reveal that the upper contact is gradational with the Wolsey Shale. Following Robinson (1963), I placed the upper contact at the base of the lowest shale 


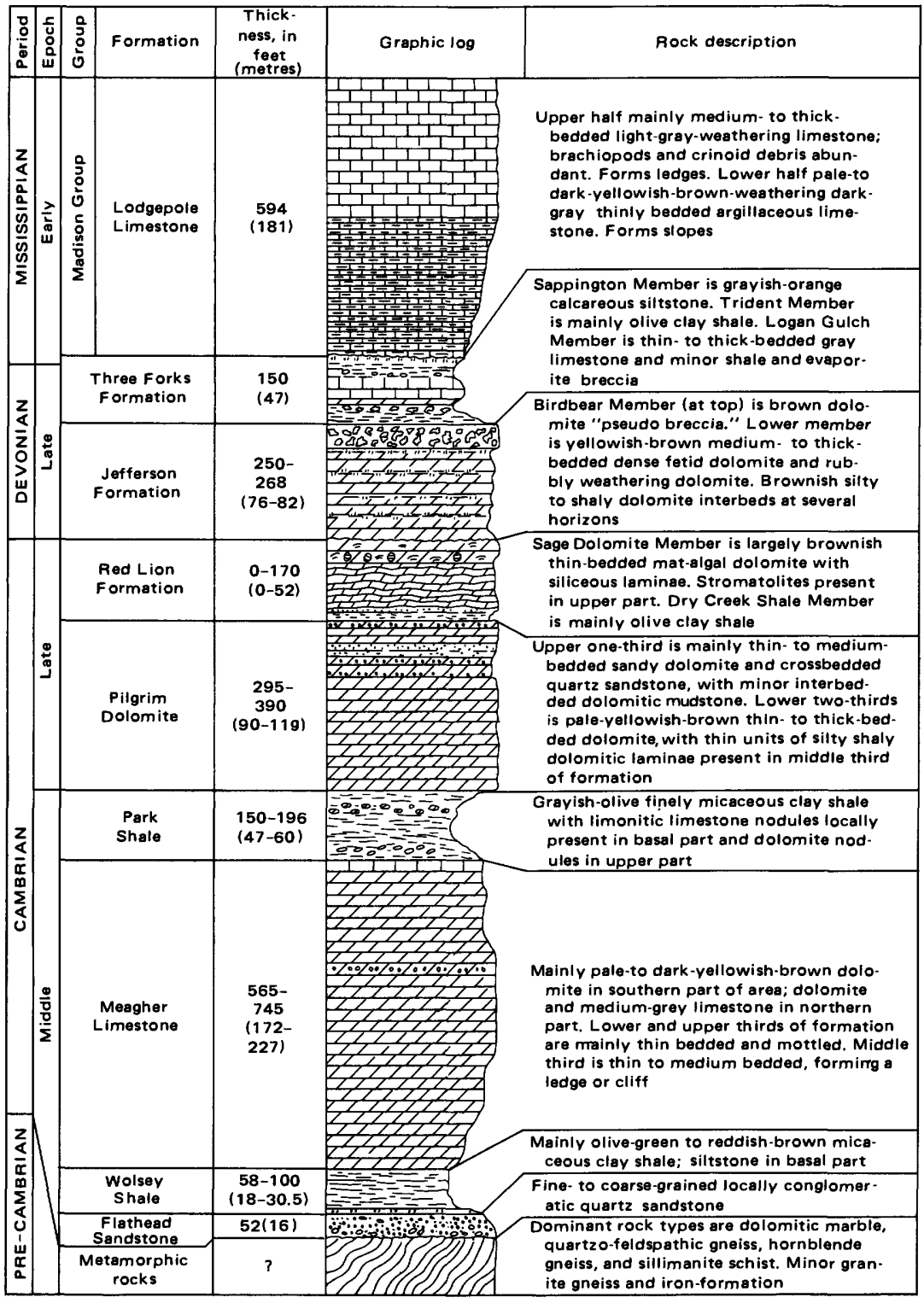

Figure 2.- Generalized columnar section of Paleozoic and Mesozoic rocks in northern part of Ruby Range.

unit that is more than 5 feet $(1.5 \mathrm{~m})$ thick. Where the shale section is covered, I placed the contact above the highest sandstone ledge beneath the dip slope of the Wolsey.

No fossils were found in the Flathead in the Ruby Range. Middle Cambrian trilobites of the genus Glossopleura are present in the 


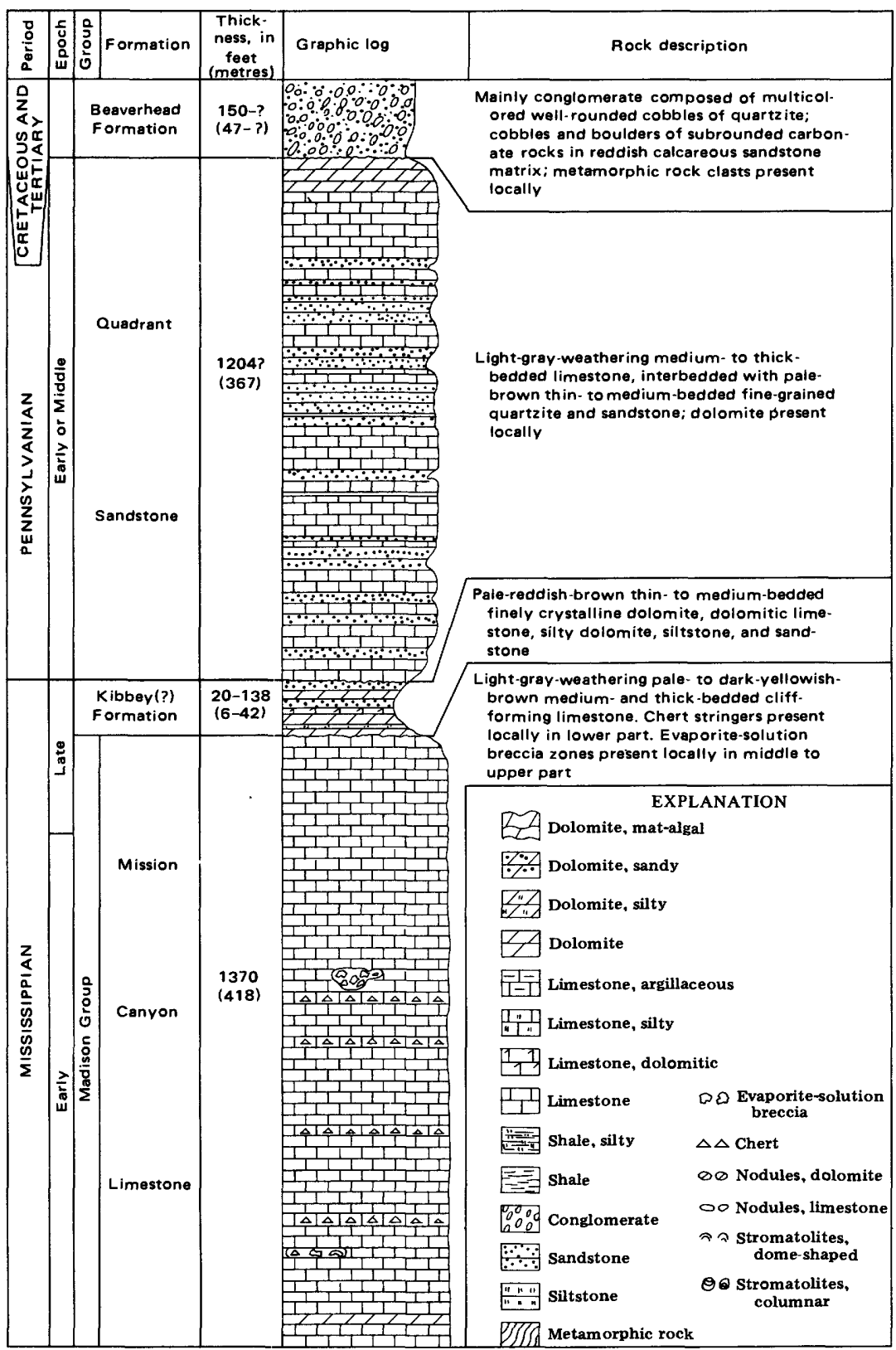

Figure 2.-Continued.

lower part of the Wolsey Shale that overlies the Flathead in the Three Forks area (fig. 4) about $40 \mathrm{mi}(64 \mathrm{~km})$ north of the mapped area (Alexander, 1955). As sedimentation was apparently continuous 


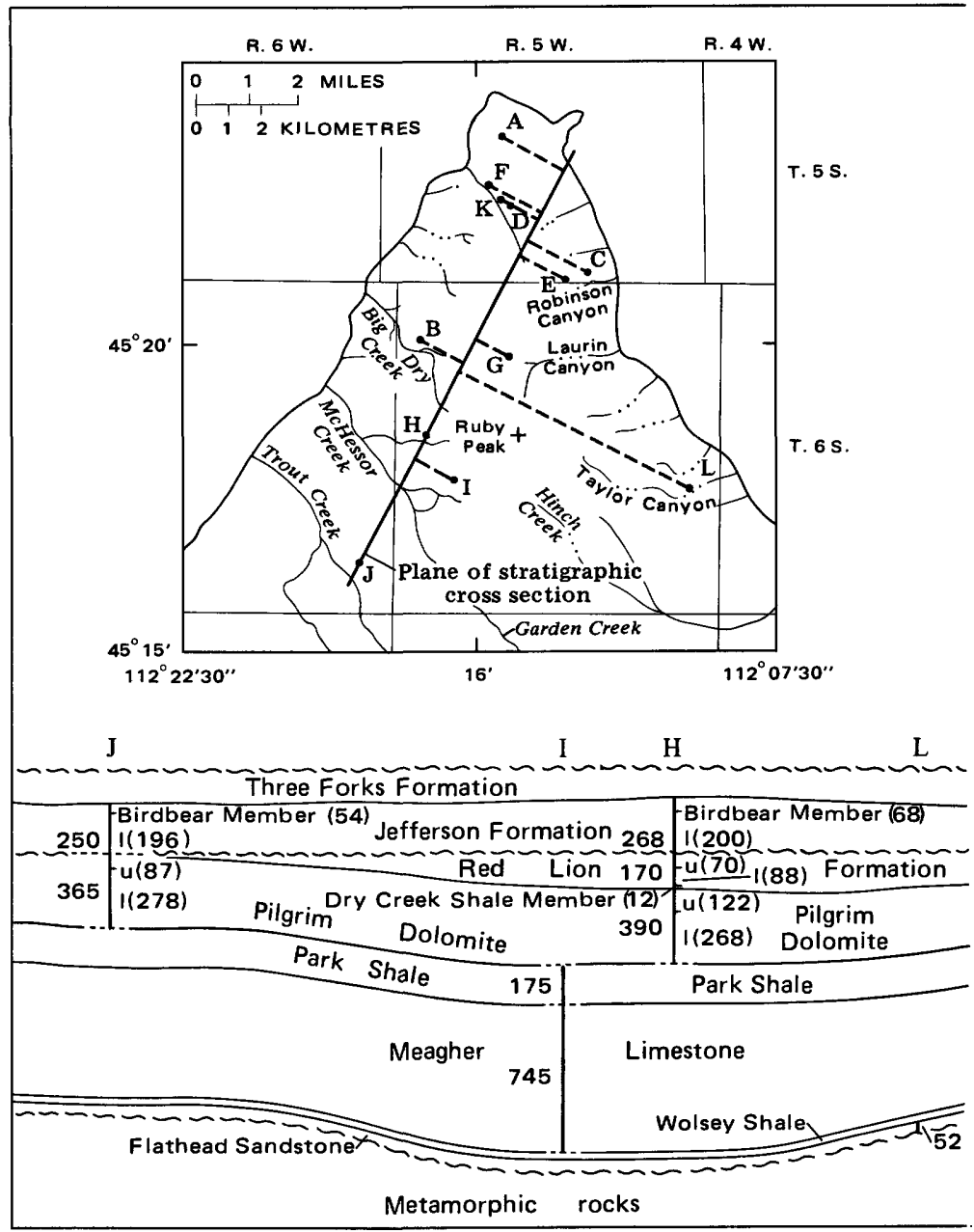

Figure 3.-Generalized stratigraphic cross section of Paleozoic rocks in northern part of Ruby Range. Locations of measured sections and plane of cross section shown in inset map.

from the base of the Flathead to fossiliferous rocks in the lower part of the overlying Wolsey, it is reasonable to infer that the Flathead is only slightly older than the Wolsey. The Flathead of the Ruby Range, therefore is believed to belong to the Glossopleura zone and (or) the Albertella zone (fig. 4). Chadhuri and Brookings (1969), who radiometrically dated glauconite from the upper part of the Flathead, obtained an age of 542 m.y., which they consider Middle Cambrian.

\section{WOLSEY SHALE}

The Wolsey Shale (fig. 3, section G) is of Middle Cambrian age, ranges from 58 to $100 \mathrm{ft}(18-30 \mathrm{~m})$ thick, commonly forms broad benches or grass-covered slopes above the Flathead Sandstone, and is 

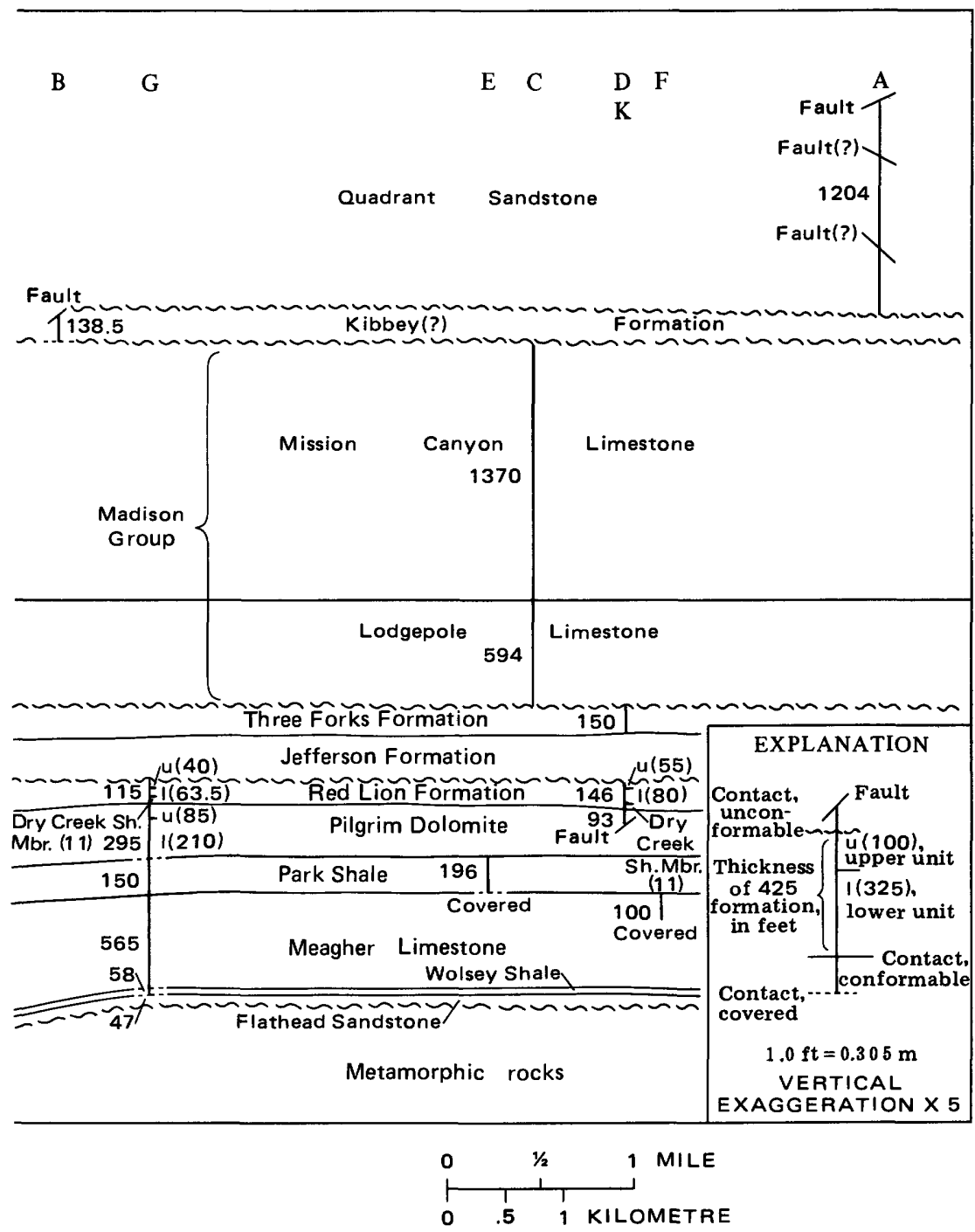

Figure 3-Continued.

exposed only in a mining exploration trench cut into the basal part of the formation (SE $1 / 4$ sec. 34, T. 6 S., R. 6 W. Beaverhead Rock SE quadrangle). It is chiefly brown, thin-bedded coarse-grained micaceous glauconitic quartzose siltstone and intercalated olive-green and reddish-brown coarsely micaceous clay shale. Shale in the upper part of the formation is like that below, except that reddish rocks were not observed. Examination of siltstone by microscopy shows quartz (85-90 percent), feldspar (5-10 percent), glauconite (1-10 percent), mica (1-2 percent), and hematite (1 percent). Most of the grains are angular to subangular (except the glauconite grains which are round) and are cemented with silica along sutured grain contacts. 


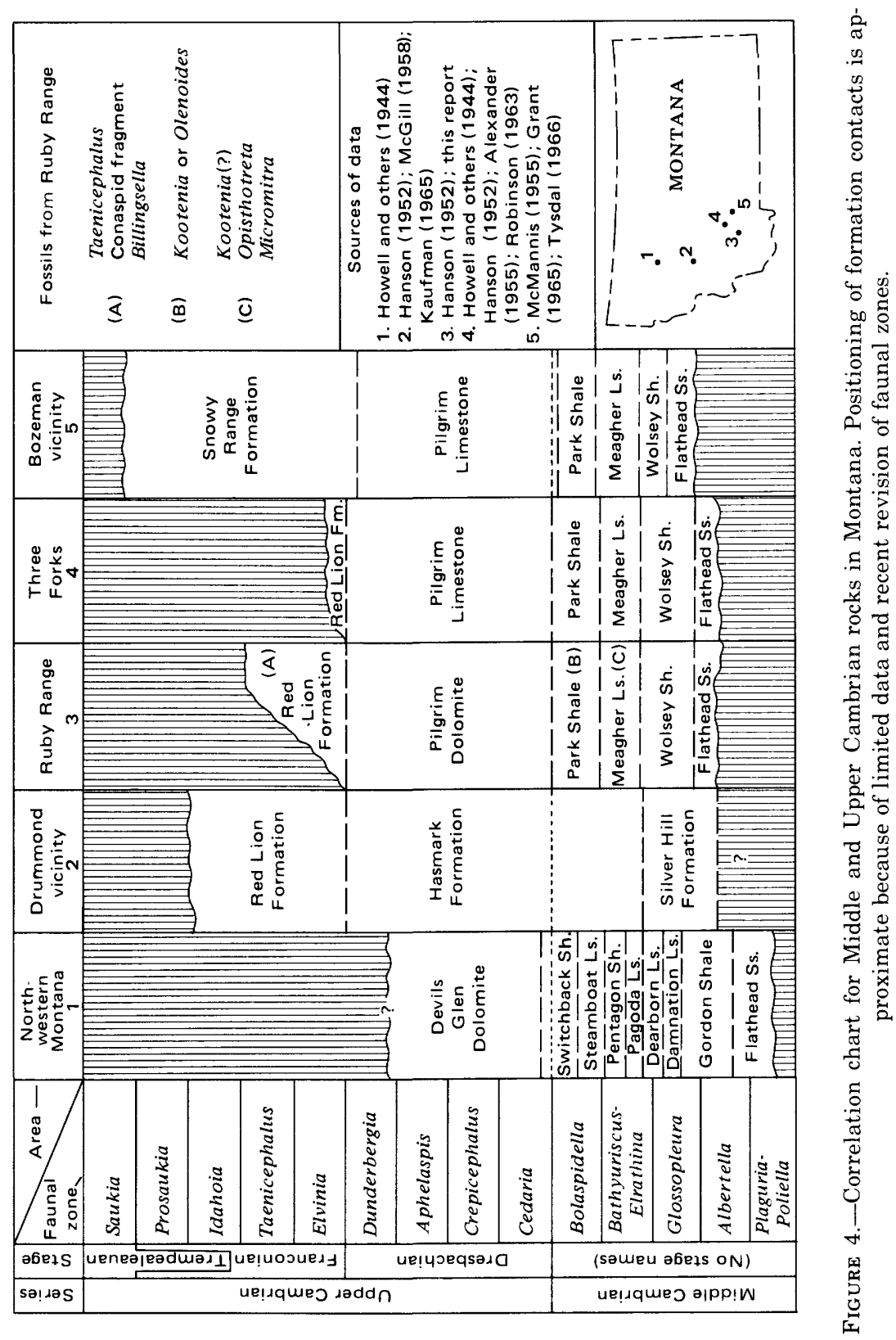


Regionally, the Wolsey is divisible into three parts: a basal shale unit with intercalated sandstone, siltstone, and shale; a medial limestone unit; and an upper shale unit that grades into the overlying Meagher Limestone (Hanson, 1952; Lebauer, 1965). The middle unit, or float from it, was not seen in the Ruby Range, and the topographic pattern does not suggest the presence of a carbonate unit.

The Wolsey-Meagher contact was not observed in the Ruby Range, but in a few places where stratified dolomite crops out near the base of the Meagher, the transitional beds must be only a few feet thick. The contact was placed at the break in slope below the outcropping carbonate beds typical of the Meagher Limestone and at the break in slope where the carbonate beds do not crop out.

No fossils were found in the Wolsey in the Ruby Range. Those reported from nearby areas include Glossopleura-zone faunas in the Jefferson Canyon and Three Forks regions (Hanson, 1952; Alexander, 1955; Robinson, 1963).

\section{MEAGHER LIMESTONE}

The Meagher Limestone (fig. 3, sections F, G, I) is Middle Cambrian in age and is the thickest Cambrian formation in the Ruby Range, ranging from 565 to $745 \mathrm{ft}(172-227 \mathrm{~m})$ thick. It is generally well exposed, except for the basal one third, and consists of pale- to dark-yellowish-brown dolomite in the McHessor Creek drainage and southward but mainly medium-gray limestone north of this drainage. The limestone and dolomite are of fine crystallinity. The middle third of the Meagher is thin and medium bedded, appears massive, and contains surficial yellowish dolomitic mottles, pisolites, and locally oolites. The lower and upper thirds are mostly thin bedded; they contain irregular yellowish mottles, the "blue-and-gold" mottled limestone (for photographs see Hanson, 1952, pl. 3-H; Lebauer, 1965). The uppermost $100 \mathrm{ft}(30 \mathrm{~m})$ of the formation is locally dolomitic limestone, pale- to dark-yellowish-brown and mottled grayish orange, and is intercalated with gray-green clay shale laminae. It contains flat- and locally edgewise-pebble conglomerate, oolites, brachiopod and trilobite fragments, and glauconite.

Lebauer (1965) described each unit of the Meagher Limestone in detail. Microscopic examination of the middle part of the Meagher shows the pisolites to be oncolites of algal filaments similar to those termed Girvanella. Whitish twiglike structures $1-3 \mathrm{~mm}$ in diameter and to $1 \mathrm{~cm}$ long are commonly associated with the oncolites or with aggregates of pellets; such structures have been noted elsewhere in the Meagher by Sloss and Moritz (1951), Hanson (1952), and Robinson (1963). Subtle small-scale long-angle crossbedding and pellets were seen in thin sections of thin-bedded limestone from the upper 
part of the formation.

Carbonate beds in the upper 50 to $100 \mathrm{ft}(15-30 \mathrm{~m})$ of the Meagher commonly intertongue with shale like that of the overlying Park Shale. The contact is therefore placed at the uppermost outcrop of Meagher-like carbonate rock. No interbedded shale is present in the thin (565 ft (172 m)) Laurin Canyon section (fig. 3, section G) so the contact must be fairly sharp.

Poorly preserved fossils from the upper $100 \mathrm{ft}(30 \mathrm{~m})$ of the Meagher in section F (fig. 3) were identified by A. R. Palmer (written commun., 1968). They include the brachiopods Micromitra and Opisthotreta, and the trilobites Kootenia?, a pygidium of either Kootenia or Olenoides, and indeterminate marjumid and bynumiid brachiopods. Palmer stated that "the total aspect***is of faunas of late Middle Cambrian age."

PARK SHALE

The Park Shale (fig. 3, sections E, G, and I) is Middle Cambrian in age, is $150 \mathrm{ft}(46 \mathrm{~m})$ to more than $196 \mathrm{ft}(60 \mathrm{~m})$ thick, and commonly forms a gently sloping grass-covered bench above the Meagher. It consists mainly of grayish-olive, finely micaceous fissile clay shale with thin-bedded yellow and orange limestone nodules near the base and dolomite nodules near the top. The limestone nodules, which weather out of the shale, contain abundant trilobite fragments, phosphatic brachiopods, oncolites, or limestone pebbles. Lochman (1957) termed the fossiliferous nodules coquina.

The dolomite nodules in Robinson Canyon (fig. 3, section E) are "pod" shaped with dimensions averaging 5 by 3 by $3 / 4$ in. ( 13 by 7.5 by $2 \mathrm{~cm}$ ). Silty dolomite forms the core of each pod, and the outer part is micaceous dolomitic siltstone. The pods are confined to the clay shale of the formation where many are present at the same stratigraphic level.

The upper contact of the Park is commonly covered, but it is exposed in Robinson Canyon (fig. 3, section E), where it is marked by an abrupt change from nonfissile dolomite mudstone in the upper 15 in. $(38 \mathrm{~cm})$ of the Park to dolomite pebble conglomerate in the basal 6 in. $(15 \mathrm{~cm})$ of the Pilgrim Dolomite. The contact here, which is not gradational, certainly indicates an abrupt change in environment if not an unconformity.

Poorly preserved fossils were collected from limestone nodules that had weathered out of the lower part of the Park in SE1/4 NE $1 / 4$ sec. 13, T. 6 S., R. 6 W. (Beaverhead Rock SE quadrangle). These fossils were identified by M. E. Taylor (written commun., 1970) as Kootenia or Olenoides, indeterminate ptychoparioids, and an indeterminate orthid brachiopod. Taylor assigned the fossils to the Middle Cambrian. 


\section{PILGRIM DOLOMITE}

The Pilgrim Dolomie (fig. 3, sections $\mathrm{G}, \mathrm{H}, \mathrm{J}$, and $\mathrm{K}$ ) ranges in thickness from 295 to $390 \mathrm{ft}(90-119 \mathrm{~m})$ and is well exposed in the Ruby Range, except for the basal few tens of feet. Two distinct units make up the formation in the Ruby Range. The lower unit, $210-278 \mathrm{ft}$ $(64-82 \mathrm{~m})$ thick, consists of light-gray-weathering, pale-yellowishbrown dense dolomite. The upper unit is $85-122 \mathrm{ft}(26-38 \mathrm{~m})$ thick and consists mainly of pale-yellowish-brown sandy laminated dolomite, fine- to medium-grained crossbedded quartz sandstone, and yellowish-brown finely crystalline dolomite in the upper part of the unit.

The lower and upper few tens of feet of the lower unit are medium to thick bedded and intensely dolomitized. Polished slabs of the rock show local occurrences of faint mottling, glauconite, white twiglike structures similar to those noted in the Meagher, and ghosts of replaced oolites.

The middle part of the lower unit is characterized by repeated alternations of thin beds of shaly laminated dolomite, laminated dolomite, mottled dolomite, dolomite-pebble conglomerate, and fossil fragmental dolomite.

The upper unit of the Pilgrim contains abundant quartz sand in laminated dolomitic rocks. In outcrop its expression is more like the Sage Dolomite Member of the overlying Red Lion Formation than the underlying part of the Pilgrim. The rocks are assigned to the Pilgrim because they underlie, and are distinct from, the olive-gray shale of the Dry Creek Shale Member of the Red Lion (Emmons and Calkins, 1913; Lochman, 1950). The sandy laminated dolomite forms thinbedded sequences, from 4 to 35 feet (1-10.5 m) thick, throughout the upper unit of the Pilgrim. The sand grains make up 20-25 percent of the rock, are subangular to subrounded, and form flat or wavy laminae that weather in relief. Crossbedded quartz sandstone occurs in only one interval in the upper unit and ranges from 4 to $12 \mathrm{ft}$ (1-3.5 $\mathrm{m})$ thick; tabular and local trough crossbeds are present with the crossbed sets ranging from 2 to 12 in. $(5-25 \mathrm{~cm})$ in thickness.

Other rocks of the upper unit of the Pilgrim include (1) lightgray-weathering dolomite, which is thinly bedded but appears massive and forms sequences 4 to $6 \mathrm{ft}(1-2 \mathrm{~m})$ thick; (2) bioclastic dolomite; (3) reddish-nodular-weathering dolomite; and, (4) at the top of the formation, reddish-mottled sandy crystalline dolomite.

The contact of the Pilgrim Dolomite with the overlying Red Lion Formation is sharp. No evidence of a disconformity was observed although Palmer (written commun., in Witkind, 1969, p. 20) notes that one may exist in southwestern Montana.

No identifiable fossils were found in the Pilgrim, presumably be- 
cause of dolomitization; fossil debris is present in the bioclastic rocks. The Pilgrim is considered Late Cambrian in age (Lochman-Balk, 1956; Robinson, 1963).

\section{RED LION FORMATION}

The Red Lion Formation (fig. 3, sections G, H, and K) is Late Cambrian in age and ranges in thickness from about 115 to $170 \mathrm{ft}$ (35$52 \mathrm{~m}$ ); it is absent in the Trout Creek drainage area. The Dry Creek Shale Member, which occurs at the base of the formation, is poorly exposed, is 11-12 (3.5-4 m) thick, and consists of grayish-olive soft fissile finely micaceous clay shale with 6-12 in. $(15-30 \mathrm{~cm})$ of blackish-red shale at the bottom. A few thin beds of pale-yellowishbrown glauconitic dolomitic quartz sandstone are present locally at the top of the member. The overlying Sage Dolomite Member is well exposed. Its basal part is characterized by $1-$ to 3 -in. $(2.5-7.5 \mathrm{~cm}$ ) thick beds of pale yellowish-brown dolomite with intercalated reddish-brown silty dolomite laminae. These "ribboned" beds are overlain by yellowish-brown finely crystalline dolomite beds $1 / 2-2$ in. $(1-5 \mathrm{~cm})$ thick, locally mottled grayish-red, and contain thin interbeds of bioclastic dolomite. The upper part of the Sage consists of light-gray-weathering, thin- to thick-bedded dense dolomite.

Polished slabs of the ribboned beds in the lower part of the Sage Dolomite Member show that each bed is actually a sandwich of medium-crystalline dolomite between thin layers of quartz silt. The thinner beds of dolomite commonly occur as boudins. Thin interbeds of mud-cracked dolomite occur in the lower part of the Sage; they consist of flat chips enveloped in reddish silt laminae that are strung out in discrete discontinuous layers.

In a small area north of McHessor Creek (section H) (sec. 13 and 18, T. 6 S., R. 5 W., Beaverhead Rock SE quadrangle), the light-grayweathering unit in the upper part of the Sage contains a variety of dolomitized stromatolites that form finely laminated beds $1 / 2$-to 2 -in. $(1-5 \mathrm{~cm})$ thick; small columns in 6- to 18 -in. $(15-46 \mathrm{~cm})$ thick beds; dome-shaped mounds measuring 1 - to $2-\mathrm{ft}(30-60 \mathrm{~cm})$ high and 2- to 4 - $\mathrm{ft}(60-120 \mathrm{~cm})$ wide; and columnar structures to $5 \mathrm{ft}(1.5 \mathrm{~m})$ high. The finely laminated algal beds dip beneath the dome-shaped mounds and are flexed over them or sharply abut them. The 6- to 18-in. (15-46 $\mathrm{cm}$ ) thick beds of stromatolites extend laterally for more than $100 \mathrm{ft}$ $(30 \mathrm{~m})$; locally the stromatolites have a thin unit of dolomite pebble conglomerate at their base. The few stromatolites preserved in the beds are columnar, 2 - to 4 -in. $(5-10 \mathrm{~cm})$ wide at the base and $4-$ to 8 -in. $(10-20 \mathrm{~cm})$ high. The small columns commonly are separate, but some are linked laterally. Dome-shaped mounds are composed mainly of many individual stromatolites similar in size to those of the 
6- to 18-in. (15-46 cm) thick beds. Each of the observed stromatolites is made of concentrically stacked hemispheroids although other types of stacking may be obscured by dolomitization. Dolomite pebble conglomerate is common at the base of each dome-shaped mound. Columnar stromatolites 4 - to 5 -ft $(1-1.5 \mathrm{~m})$ high are typically 1 - to $2-\mathrm{ft}$ $(30-60 \mathrm{~cm})$ wide at the base and taper upward. The form is discrete, being composed of vertically stacked hemispheroids in which the upper laminae do not reach the base of the preceding ones.

The upper part of the Sage Dolomite Member was mistakenly assigned to the Bighorn Dolomite (Ordovician) by Hanson (1952). It is conformable with the underlying part of the Sage, and a Late Cambrian (conaspid) trilobite was obtained from its uppermost part about $165 \mathrm{ft}(50 \mathrm{~m})$ above the base of the Red Lion. Fossils collected about 60 $\mathrm{ft}(18 \mathrm{~m})$ above the base of the Red Lion in measured section $\mathrm{H}$ were identified by A. R. Palmer (written commun., 1968; 1970). They include the brachiopod Billingsella and the trilobite Taenicephalus. The fossils are of Late Cambrian (Franconian) age.

\section{DEVONIAN SYSTEM}

JEFFERSON FORMATION

The Jefferson Formation (fig. 3, sections $\mathrm{H}$ and J), of Late Devonian age, unconformably overlies the Red Lion Formation, ranges from 250 to $268 \mathrm{ft}$ (76-82 m) thick, and is well exposed. Sandberg (1962, 1965) divided the formation into a lower unnamed member and the overlying Birdbear Member. The lower member is marked by repetition of three kinds of rock: (1) yellowish-brown to grayish-orange silty shaly dolomite "detrital units" of Benson (1966); (2) pale- to darkyellowish-brown medium- to thick-bedded fine- to mediumcrystalline rubbly weathering dolomite; and (3) pale- to darkyellowish-brown, medium- and thick-bedded, finely crystalline dense fetid and, locally, sugary dolomite. The Birdbear Member, which ranges from 54 to $68 \mathrm{ft}$ (16-21 m) thick in the Ruby Range, contains thinly bedded dolomite in its basal $9-12 \mathrm{ft}(3-4 \mathrm{~m})$ but is mainly ledge-forming dolomite breccia and "pseudobreccia" (Sandberg, 1965). The massive unit is mostly pale yellowish brown; locally the upper few feet are mottled grayish orange.

The silty, shaly, and detrital dolomite beds of the lower member are thinly bedded and locally consist of fine laminae that weather into 1-mm-thick "pages" to form "books." The uppermost detrital unit marks the top of the lower member; according to Benson (1966), it is traceable from northeastern Montana to northeastern Utah.

The rubbly-weathering dolomite has a very uneven, weathered outcrop face on each bed. At one place, where a rubbly bed was traced 
laterally into a less well exposed outcrop, the outcrop face was much smoother. The origin of the rubbly beds is uncertain, but the beds may have formed by evaporite solution.

The Jefferson is thinner in the Ruby Range than in nearby areas to the east, north, or west (compare Mann, 1954, 1960; Hadley, 1960; Karlstrom, 1948; Johns, 1961); it overlies an erosionally thinned Cambrian section in the southern part of the map area. These data, and the regional data of Benson (1966), suggest depositional thinning of the formation southward toward a positive area in the Devonian sea, the Tendoy dome (Lemhi Arch) (Sloss, 1954; Scholten, 1957, 1960; Scholten and Hait, 1962), and the Yellowstone Park uplift (Sandberg and Mapel, 1967; Mapel and Sandberg, 1968).

Except for Amphipora, fossils were not found in the Jefferson of the Ruby Range. The Late Devonian age of the formation is based on regional faunal data (compare Robinson, 1963; Sandberg and Mapel, 1967; Witkind, 1969).

\section{DEVONIAN AND MISSISSIPPIAN SYSTEMS}

THREE FORKS FORMATION

The Three Forks Formation (fig. 3, section D) is about $150 \mathrm{ft}(47 \mathrm{~m}$ ) thick; except for a medial limestone unit, it is poorly exposed. It consists of three members, in ascending order, the Logan Gulch, Trident, and Sappington Members (Sandberg, 1965). The Logan Gulch Member is $110 \mathrm{ft}(34 \mathrm{~m})$ thick in the Ruby Range; its lower half consists of yellowish-brown, thin- to thick-bedded dolomite and limestone evaporite-solution breccia, and a few interbeds of greenish-gray clay shale. The upper half of the member is composed mainly of gray-weathering, thin- and thick-bedded, finely crystalline limestone. It forms a prominent ledge that serves as an excellent marker unit throughout the range. The rest of the formation is covered, except for $7 \mathrm{ft}(2 \mathrm{~m}$ ) of grayish-orange thin- to medium-bedded, calcareous siltstone in the upper part of the covered interval assigned to the Sappington Member.

Between the exposed parts of the Logan Gulch Member and the Sappington Member is a covered interval about $25 \mathrm{ft}(8 \mathrm{~m})$ thick that may represent both the Trident Member and parts of the Sappington Member. Float from the basal half of the covered interval is mostly pale-olive chips of micaceous clay shale similar to that described at the type area of the Three Forks by numerous workers. An attempt was made, without success, to expose beds immediately beneath the siltstone in search of a black shale unit that occurs at the base of the Sappington as defined by McMannis (1955) in the Three Forks region. It is therefore uncertain if the black shale unit is present here. 
The Jefferson-Logan Gulch contact is sharp and appears conformable. The Logan Gulch-Trident, Trident-Sappington, and Sappington-Lodgepole contacts are all covered.

The faunal elements listed below, collected from the Logan Gulch Member in $\mathrm{NW}^{1 / 4} \mathrm{SE}^{1 / 4}$ sec. 18, T. 6 S., R. 5 W. (Beaverhead Rock SE quadrangle) (section not measured), were identified by J. T. Dutro, Jr. (written commun., 1968). They are of Late Devonian age, probably middle Famennian.

Schuchertella sp.

"Camarotochia" sp.

Crytospirifer monticola (Haynes)

Crytospirifer sp.

Crytiopsis sp.

Cleiothyridina devonica Raymond

\section{MISSISSIPPIAN SYSTEM}

\section{MADISON GROUP}

A thick sequence of carbonate beds, about $1,960 \mathrm{ft}$ (588 m), overlying the Devonian rocks makes up the Madison Group. The lower one-third of the sequence is assigned to the Lodgepole Limestone, the remaining two-thirds to the Mission Canyon Limestone. The group forms prominent outcrops along much of the east and north flanks of the range.

\section{LODGEPOLE LIMESTONE}

The Lodgepole Limestone (fig. 3, section C) is $594 \mathrm{ft}(181 \mathrm{~m})$ thick near Robinson Canyon in the northern part of the mapped area, and this thickness seems uniform throughout the range. The upper half is commonly well exposed throughout the mapped area; the lower half is well exposed mainly along the eastern margin of the range where the beds dip steeply. Most of the lower $300 \mathrm{ft}(91 \mathrm{~m})$ of the Lodgepole is made up of pale- to dark-yellowish-brown-weathering, 2- to 5-in. $(5-13 \mathrm{~cm})$ thick beds of dark-gray laminated argillaceous limestone; the laminae weather into "books" of 1-mm-thick "pages." The upper part of the formation is composed of light-gray-weathering mediumand thick-bedded finely crystalline limestone, and locally of medium-crystalline beds containing clastic debris.

Limited thin-section studies of the argillaceous limestone reveal an abundance of clay pellets $15-60 \mu \mathrm{m}$ in diameter; the size range in any one thin section is commonly much narrower. Cherty particles constitute 10 percent or more of the beds; finely comminuted fossil debris makes up a smaller fraction. The matrix of the rock is finely cr."stalline limestone. 
The lower rocks of the Lodgepole in the Ruby Range differ from those in nearby areas where they have been described as thinly bedded limestone with partings of shaly limestone or calcareous shale. In the Ruby Range, it is the shaly rocks that make up most of the sequence.

The Cottonwood Canyon Member of the Lodgepole (Sandberg and Klapper, 1967), a thin black shale unit present at the base of the formation in much of Montana and northern Wyoming, was not observed in the Ruby Range, but as the contact interval is not exposed, the unit may be present but concealed. If present, the member must be thin, for the covered interval is only $9 \mathrm{ft}(3 \mathrm{~m})$ thick where the Three Forks was measured. Isopach maps of Benson (1966) and Sandberg and Klapper (1967) show the unit to be absent or very thin $(2-3 \mathrm{ft}(60-90 \mathrm{~cm}))$ in the general area, and Sando and Dutro (1960) state that it is absent in the nearby Gravelly Range.

Sloss and Hamblin (1942) divided the Lodgepole into the Paine Member and the overlying Woodhurst Member, placing the contact at the base of massive beds of crinoidal debris. Massive beds were not observed in the Lodgepole in the Ruby Range, and the contact between the lower and upper parts is transitional through tens of feet. Therefore the Paine-Woodhurst terminology is not used here.

The contact of the Lodgepole with the overlying Mission Canyon Limestone, which is conformable, was placed at the base of the first cliff-forming outcrop.

Many fossils occur in the Lodgepole, particularly in the upper half; their stratigraphic distribution is shown in table 1. (See section $\mathrm{C}$ of open-file report (Tysdal, 1970) for detailed description of rocks.) The fossils are Early Mississippian. They were identified by J. T. Dutro, Jr. (written commun., 1968), who states, "the assemblage is typical of the middle and upper parts of the Lodgepole Limestone in southwestern Montana and can be assigned to Zone $\mathrm{C}_{1}$ of Sando and Dutro (1960)."

\section{MISSION CANYON LIMESTONE}

The Mission Canyon Limestone (fig. 3, section C) forms the steep eastern slopes of the Ruby Range and is well exposed in narrow canyons cut across the strike of the beds. The beds are not so well exposed elsewhere in the range. A thickness of $1,370 \mathrm{ft}$ (418 m) was measured near Robinson Canyon; this figure is considered approximate because the measurement was necessarily made on a dip slope.

The Mission Canyon consists mainly of pale- to dark-yellowishbrown, medium- and thick-bedded limestone that weathers light gray and forms ledges and cliffs. The only dolomite observed was a $30-\mathrm{ft}$ $(9 \mathrm{~m})$ thick interval in the lower one-fourth of the formation. Crystal- 
TABLE 1. Stratigraphic position of fossils collected from the Mississippian Lodgepole Limestone

[Identifications by J. T. Dutro, Jr ]

\begin{tabular}{|c|c|c|c|c|c|c|c|c|c|c|c|c|c|c|}
\hline & $\begin{array}{l}\text { U.S. Geological Survey } \\
\text { Locality No. }\end{array}$ & 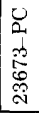 & 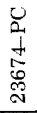 & $\begin{array}{l}0 \\
0 \\
d \\
D \\
0 \\
\infty \\
\infty \\
N\end{array}$ & \begin{tabular}{l}
0 \\
0 \\
0 \\
\multirow{0}{0}{} \\
$\tilde{c}$
\end{tabular} & 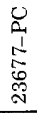 & $\begin{array}{l}c \\
0 \\
\frac{1}{2} \\
5 \\
0 \\
\text { N }\end{array}$ & 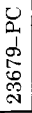 & $\begin{array}{l}0 \\
0 \\
d \\
0 \\
0 \\
0 \\
\text { N }\end{array}$ & 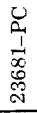 & 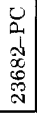 & $\begin{array}{l}0 \\
0 \\
\infty \\
0 \\
0 \\
0 \\
0\end{array}$ & $\begin{array}{l} \\
2 \\
d \\
0 \\
0 \\
0 \\
\text { N }\end{array}$ & 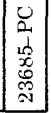 \\
\hline Fossils & $\begin{array}{l}\text { Feet above base, } \\
\text { measured section } \mathrm{C}\end{array}$ & 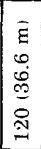 & $\begin{array}{l}\overline{\mathrm{g}} \\
0 \\
0 \\
0 \\
0 \\
0 \\
\vec{\sigma}\end{array}$ & $\begin{array}{l}\bar{E} \\
\infty \\
\dot{\infty} \\
\stackrel{\infty}{N} \\
\stackrel{5}{N}\end{array}$ & 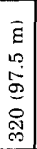 & 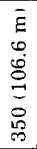 & 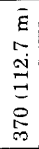 & $\begin{array}{c}\bar{E} \\
\infty \\
0 \\
\mathscr{I} \\
= \\
\overline{0} \\
\infty \\
+\end{array}$ & 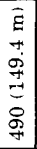 & 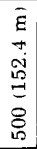 & 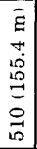 & $\begin{array}{c}\bar{\varepsilon} \\
0 \\
-1 \\
0 \\
0 \\
0 \\
0 \\
0 \\
0\end{array}$ & 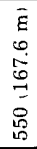 & $\bar{E}$ \\
\hline
\end{tabular}

Echinoderms:

Platycrinites

Echinoderm debris, indet

Coelenterates:

Horn coral, indet

Conularia? sp.

Bryozoans:

Sulcoretopora sp.

Ptilopora sp.

Fenestrate bryozoans, indet

Ramose bryozoans, indet

Bryozoans, indet

Brachiopods:

Rhipidomella sp

Leptagonia cf. L. analoga

Schuchertella? sp

Axiodeania? sp

Rhynchonellid brachiopods, indet

Retichonetes logani

(Norwood and Pratten)

$R$ ugosochonetes $\mathrm{cf}$. $R$. loganensis

(Hall and Whitfield)

Productoid brachiopod, indet

Unispirifer sp

Spirifer cf. S. gregeri Weller.........

Actinochonchus sp.

Syringothyroid, indet

Composita sp.

Cleiothyridina cf.

C. tenuilineata (Rowley)

C. cf C. obmaxima (McChesney)

Punctospirifer cf. P. solidirostis (White)Ambocoelia? sp

Eumetria? sp

Gastropods:

Straporollid gastropod, indet

Trace Fossils:

Worm tubes and burrows, indet

linity ranges from fine to coarse; much of the rock is coarsely recrystallized. A few chert stringers are present in the middle third of the formation.

Solution breccias that fill cavities $20-50 \mathrm{ft}(6-15 \mathrm{~m})$ across in the upper part of the Mission Canyon consist of fragments of Mission Canyon Limestone to $3 \mathrm{ft}(1 \mathrm{~m})$ in diameter; the fragments are chaotically arrayed and are cemented by grayish-orange silty limestone 
that is silicified locally. Similar breccias have been described in the Mission Canyon at numerous localities in Montana (compare Sloss and Hamblin, 1942; and Roberts, 1966).

The lower contact is conformable with the Lodgepole, as noted. The upper contact, though not observed, is inferred to be unconformable with the Kibbey(?) Formation on the basis of data from nearby areas (Robinson, 1963; Huh, 1967; Witkind, 1969).

No fossils were found in the Mission Canyon Limestone. Its age is considered Early and Late Mississippian.

\section{KIBBEY(?) FORMATION}

The Kibbey(?) Formation (fig. 3, section B) ranges in thickness from 20 to $138 \mathrm{ft}(6-42 \mathrm{~m})$, is poorly exposed, and makes a reddish soil-covered interval-except for the well-exposed outcrop near Big Dry Creek that was measured for section B. At this outcrop the unit consists mainly of pale-reddish-brown, thin- to medium-bedded, finely crystalline silty dolomite or dolomitic limestone, with localized interbeds of calcareous quartz sandstone. Some of the beds are mottled; the mottled parts are rounded dolomite intraclasts as much as $8 \mathrm{~mm}$ in diameter. A few other beds contain algal laminations. Quartz silt grains ranging from 20 to $60 \mu \mathrm{m}$ in diameter make up 10-20 percent of some beds. The sandstone interbeds are composed largely of rounded fine- to medium-grained quartz, but chert grains locally constitute 10-15 percent of the rock.

The difficulty in distinguishing red beds of the Mississippian Kibbey Formation of the Big Snowy Group from those of the Mississippian and Pennsylvanian Amsden Formation has long been recognized (McMannis, 1965; Maughan and Roberts, 1967). A recent study of the Big Snowy Group (Harris, 1972) and its relation to the Amsden Formation in central and part of southwestern Montana traces the Big Snowy and Amsden rocks into the Three Forks-Jefferson Canyon area (fig. 1); there Harris distinguishes the red beds in the Kibbey from those in the Amsden on the basis of color, presence or absence of pinkish chert, and presence or absence of quartz sand. The Kibbey is characterized by an intense red color, the Amsden by somber hues of grayish red, maroon, and pale brown. Pinkish chert is common in the Kibbey but apparently absent from the Amsden. The Kibbey contains a significant amount of quartz sand but quartz sand is nearly absent from the Amsden. Using these criteria, the red beds in the Ruby Range are more like those of the Kibbey than the Amsden, therefore they are questionably assigned to the Kibbey.

The contact of the Kibbey(?) with the overlying Quadrant Sandstone is sharp. Red rocks are not interbedded with the Quadrant.

Fossils were not found in the Kibbey(?), but the age is considered 
Late Mississippian, the age of the Kibbey in the nearby Gravelly Range (Hadley, 1960) and the Three Forks area (Robinson, 1963).

\section{PENNSYLVANIA SYSTEM \\ QUADRANT SANDSTONE}

The Quadrant Sandstone is present only at the north end of the range (fig. 3, section A) in an exposure containing $1,200 \mathrm{ft}(366 \mathrm{~m})$ of contorted, brecciated, and faulted limestone, dolomite, and sandstone; the minimum thickness is about $300 \mathrm{ft}(91 \mathrm{~m})$, the maximum more than $1,200 \mathrm{ft}(366 \mathrm{~m})$. The formation consists of well-exposed light-gray-weathering medium-and thick-bedded limestone in intervals as much as $40 \mathrm{ft}(12 \mathrm{~m})$ thick; the limestone is interbedded with poorly exposed pale-brown thin- to medium-bedded quartzite in intervals of similar thickness. The limestone, and locally dolomite, is finely crystalline; it contains varying percentages of fossil debris, algal-laminated limestone, and calcareous pellets. Recrystallization has obscured most of the fauna. The quartzitic sandstone is well sorted; it is composed of grains ranging between 60 and $150 \mu \mathrm{m}$ in diameter which are cemented mostly by silica overgrowths. Float from the covered intervals in the section is composed largely of the quartzitic sandstone.

The actual thickness of the Quadrant is uncertain because of deformation and the absence of younger Paleozoic rocks. The minimum unfaulted thickness, about $300 \mathrm{ft}(91 \mathrm{~m})$, is consistent with that measured northward in the Jefferson Canyon area (Berry, 1943; Alexander, 1955; Robinson, 1963) and eastward and southeastward in the Gravelly and Madison Ranges, and the Centennial Mountains (Condit, 1918; Scott, 1935; Gardner and others, 1945; Honkala, 1949; Sloss and Moritz, 1951; Hadley, 1960; and Maughan and Roberts, 1967). Thicker sequences, more than $700 \mathrm{ft}(213 \mathrm{~m})$, have been reported in the area of McCartney Mountain west of the Ruby Range (Pardee, in Richards and Pardee, 1925; Sloss and Moritz, 1951); more than $500 \mathrm{ft}$ $(152 \mathrm{~m})$ is present in the northern Snowcrest Range (Mann, 1954), and more than $1,000 \mathrm{ft}(305 \mathrm{~m})$ is reported in the Blacktail Range south of the Ruby Range (Scholten and others, 1955).

Fossils collected from the Quadrant, about $910 \mathrm{ft}(277 \mathrm{~m})$ above the base of the measured section, are Anthracospirifer aff. A. occidus (Sadlick) and Composita aff. C. subtilita Hall. They were identified and assigned an Early or Middle Pennsylvanian age by J. T. Dutro, Jr. (written commun., 1968).

\section{MESOZOIC ROCKS}

The only Mesozoic rocks preserved in the Ruby Range are those of 
the Beaverhead Formation, the lower part of which is Cretaceous. Triassic, Jurassic, and pre-Beaverhead Cretaceous rocks are absent, largely due to erosion, but in part to nondeposition (see isopach maps of McMannis, 1965; Peterson, 1972; and McGookey and others, 1972). In the nearby Gravelly and Greenhorn Ranges to the east of the mapped area, Hadley (1960) measured 225-375 ft $(67-114 \mathrm{~m})$ of Triassic rocks, $330-400 \mathrm{ft}(100-122 \mathrm{~m})$ of Jurassic rocks, $750-1,300 \mathrm{ft}$ $(229-396 \mathrm{~m})$ of Lower Cretaceous rocks, and about 3,000 ft $(915 \mathrm{~m})$ of Upper Cretaceous rocks.

\section{CRETACEOUS SYSTEM}

BEAVERHEAD FORMATION

The Beaverhead Formation in the Ruby Range is made up of three types of conglomerate; the first type is composed of carbonate clasts derived largely from the Madison Group, the second is composed of poorly exposed quartzite clasts eroded from the Precambrian Belt Supergroup, and the third, present only locally, is composed of clasts derived from the Meagher and Flathead Formations, the Belt Supergroup, and metamorphic rocks.

The carbonate conglomerate is made up of poorly sorted subrounded cobbles and boulders $2-3 \mathrm{ft}(0.5-1.0 \mathrm{~m})$ in diameter in a matrix of fine- to coarse-grained sand of limestone, quartz, and chert that is cemented by calcite and stained red by iron oxide. This conglomerate is the oldest unit of the Beaverhead in the northern part of the Ruby Range. It is exposed along the western margin of the range, where it overlies formations ranging from the Cambrian Meagher through the Mississippian Mission Canyon. It is in contact with Precambrian metamorphic rocks only along faults.

The quartzite conglomerate overlying the carbonate conglomerate is composed of well-sorted, rounded to well-rounded cobbles and locally boulders in a matrix of medium- to coarse-grained quartz sand stained red with iron oxide. Many of the clasts are highly polished and some exhibit percussion marks.

The third type of conglomerate is composed of clasts derived from the Meagher, Flathead, Belt, and metamorphic rock units and has a reddish sandstone matrix of quartz and limestone grains. It is present in only two places in the mapped area, both high up in the northern part of the Ruby Range: one about $1 \mathrm{mi}(1.5 \mathrm{~km})$ southwest of section $\mathrm{J}$, the other about $1.5 \mathrm{mi}(2.5 \mathrm{~km})$ south-southwest of this section. This conglomerate unit is considered to be the youngest part of the Beaverhead because it contains clasts derived from the oldest part of the sequence in the range and thus from rock units that would have been exposed late in the course of uplift and erosion of the range. The cobbles of Belt present in the unit were derived from rocks several 
miles west of the Ruby Range and transported into the area by streams.

The thickness of the Beaverhead was not measured but is probably several hundreds of feet.

Fossils were not found in the Beaverhead in the Ruby Range. A minimum age is late Eocene, as Petkewich (1972) found vertebrate fauna of that age in the lower part of basinal deposits that lap onto the north end of the range. In its type area, the Beaverhead contains fossils of Late Cretaceous and Paleocene age (Yen, in Lowell and Klepper, 1953; Wilson, 1970; Ryder and Ames, 1970). Ryder and Scholten (1973) believe the uppermost part of the formation may be as young as Eocene.

\section{REFERENCES CITED}

Alexander, R. G., 1955, Geology of the Whitehall area, Montana: Yellowstone-Bighorn Research Contr. 195, $111 \mathrm{p}$.

Benson, A. L., 1966, Devonian stratigraphy of western Wyoming and adjacent areas: Am. Assoc. Petroleum Geologists Bull., v. 50, p. 2566-2603.

Berry, G. W., 1943, Stratigraphy and structure at Three Forks, Montana: Geol. Soc. America Bull., v. 54, p. 1-29.

Chaudhuri, S., and Brookings, D. G., 1969, The isotopic age of the Flathead Sandstone (Middle Cambrian), Montana: Jour. Sed. Petrology, v. 39, p. 364-368.

Condit, D. D., 1918, Relations of late Paleozoic and early Mesozoic formations of southwestern Montana and adjacent parts of Wyoming: U.S. Geol. Survey Prof. Paper 120-F, p. F111-F121.

Dorr, J. A., and Wheeler, W. H., 1964, Cenozoic paleontology, stratigraphy, and reconnaissance geology of the Upper Ruby River basin, southwestern Montana: Michigan Univ. Contr. Mus. Paleontology, v. 13, p. 297-339.

Douglass, Earl, 1905, Some notes on the geology of southwesterrn Montana: Carnegie Mus. Annals, v. 3, p. 407-428.

1909, A geological reconnaissance in North Dakota, Montana and Idaho; with notes on Mesozoic and Cenozoic geology: Carnegie Mus. Annals, v. 5, p. 211-288.

Emmons, W. H., and Calkins, F. C., 1913, Geology and ore deposits of the Philipsburg quadrangle, Montana: U.S. Geol. Survey Prof. Paper 78, 271 p.

Fields, R. W., and Petkewich, R. M., 1967, Tertiary stratigraphy and geologic history of the Upper Jefferson, Ruby, Lower Beaverhead, and Lower Big Hole River valleys, in Centennial Basin of southwestern Montana: Montana Geol. Soc. 18th Ann. Field Conf. Guidebook, p. 71-78.

Gardner, L. S., Hendricks, T. A., Hadley, H. D., and Rogers, C. P., Jr., 1945, Columnar sections of Mesozoic and Paleozoic rocks in the mountains of south-central Montana: U.S. Geol. Survey Oil and Gas Inv. Chart 18.

Garihan, J. M., 1973, Structural and metamorphic history of the pre-Beltian rocks of the central Ruby Range, southwestern Montana: Geol. Soc. America Ann. Mtg., Abstracts with Programs, v. 5, no. 7, p. 164.

Giletti, B. J., 1966, Isotopic ages from southwestern Montana: Jour. Geophys. Research, v. 71 , p. $4029-4036$.

1968, Isotopic geochronology of Montana and Wyoming, in Radiometric dating for geologists: New York, Interscience Pub., p. 111-146.

Giletti, B. J., and Gast, P. W., 1961, Absolute age of Precambrian rocks in Montana and Wyoming: New York Acad. Sci. Annals, v. 91, p. 454-458. 
Goddard, E. N. (chm.), and others, 1948, Rock color chart: Washington, D. C., Natl. Research Council, reprinted by Geol. Soc. America, 1951.

Grant, R. A., 1965, Faunas and stratigraphy of the Snowy Range Formation, southwestern Montana and northwestern Wyoming: Geol. Soc. America Mem. 96, 171 p.

Hadley, J. B., 1960, Geology of the northern part of the Gravelly Range, Madison County, Montana, in West Yellowstone-Earthquake area: Billings Geol. Soc. 11th Ann. Field Conf. Guidebook, p. 149-153.

Hanson, A. M., 1952, Cambrian stratigraphy in southwestern Montana: Montana Bur. Mines and Geology Mem. 33, 46 p.

Harris, W. L., 1972, Upper Mississippian and Pennsylvanian sediments of central Montana: Montana Univ., Missoula, Ph.D. dissert.

Hayden, F. V., 1872, Preliminary report of the United States Geological Survey of Montana and portions of adjacent territories, being a fifth annual report of progress: Washington, D. C., 538 p.

Heinrich, E. W., 1953, Pre-Beltian geologic history of Montana [abs.]: Geol. Soc. America Bull., v. 64 , p. 1432 .

1960 , Geology of the Ruby Mountains, part 2, in Pre-Beltian geology of the Cherry Creek and Ruby Mountains areas, southwestern Montana: Montana Bur. Mines and Geology Mem. 38, p. 15-40.

Honkala, F. S., 1949, Geology of the Centennial region, Beaverhead County, Montana: Michigan Univ., Ph.D. dissert., 145 p.

Howell, B. F., and others, 1944, Correlation of the Cambrian formations of North America: Geol. Soc. America Bull., v. 55, p. 993-1003.

Huh, O. K., 1967, The Mississippian system across the Wasatch line, east-central Idaho, extreme southwestern Montana, in Centennial Basin of southwestern Montana: Montana Geol. Soc. 18th Ann. Field Conf. Guidebook, p. 31-62.

James, H. L., and Wier, K. L., 1972, Geologic map of the Kelly iron deposit, sec. 25, T. 6 S., R. 5 W., Madison County, Montana: U.S. Geol. Survey Misc. Field Studies Map MF-349.

James, H. L., Wier, K. L., and Shaw, K. W., 1969, Map showing lithology of Precambrian rocks in the Christensen Ranch and adjacent quadrangles, Madison and Beaverhead counties, Montana: U.S. Geol. Survey open-file report.

Johns, W. M., 1961, Geology and ore deposits of the southern Tidal Wave mining district, Madison County, Montana: Montana Bur. Mines and Geology Bull. 24, $53 \mathrm{p}$.

Karlstrom, T. N. V., 1948, Geology and ore deposits of the Hecla mining district, Beaverhead County, Montana: Montana Bur. Mines and Geology Mem. 25, 87 p.

Kauffman, M. E., 1965, Cambrian stratigraphy in the Drummond-Garnet Range area, in Geology of the Flint Creek Range, Montana: Billings Geol. Soc. 18th Ann. Field Conf. Guidebook, p. 79-88.

Klepper, M. R., 1950, A geologic reconnaissance of parts of Beaverhead and Madison counties, Montana: U.S. Geol. Survey Bull. 969-C, p. C55-C84.

Lebauer, L. R., 1965, Genesis and environment of deposition of the Meagher Formation in southwestern Montana: Jour. Sed. Petrology, v. 35, p. 428-447.

Lochman, Christina, 1950, Status of Dry Creek Shale of central Montana: Am. Assoc. Petroleum Geologists Bull., v. 34, p. 2200-2222.

1957, Paleoecology of the Cambrian in Montana, in Ladd, H., ed., Treatise on marine ecology and paleoecology, v. 2, Paleoecology: Geol. Soc. America Mem. 67, p. $117-162$.

Lochman-Balk, Christina, 1956, The Cambrian of the Rocky Mountains and southwest deserts of the United States and adjoining Sonora Province, Mexico: Internat. Geol. Cong., 20th, Mexico, 1956, v. 2, pt. 2, p. 529-661.

Lowell, W. R., and Klepper, M. R., 1953, Beaverhead Formation, a laramide deposit in 
Beaverhead County, Montana: Geol. Soc. America Bull., v. 64, p. 235-244.

McGill, G. E., 1958, Geology of the northwest flank of the Flint Creek Range: Princeton Univ., Princeton, N. J., Ph.D. dissert.

McGookey, D. P., Haun, J. D., Hale, L. A., Goodell, H. G., McCubbin, D. G., Weimer, R. J., and Wulf, G. R., 1972, Cretaceous system, in Geologic atlas of the Rocky Mountain region: Denver, Rocky Mtn. Assoc. Geologists, p. 190-228.

McMannis, W. J., 1955, Geology of the Bridger Range, Montana: Geol. Soc. America Bull., v. 66 , p. $1385-1430$.

1965, Resume of depositional and structural history of western Montana: Am. Assoc. Petroleum Geologists Bull., v. 49, p. 1801-1823.

Mann, J. A., 1954, Geology of part of the Gravelly Range, Montana: YellowstoneBighorn Research Proj. Contr. 190, 92 p.

-1960 , Geology of part of the Gravelly Range area, Montana, in West Yellowstone-Earthquake area: Billings Geol. Soc. 11th Ann. Field Conf. Guidebook, p. 114-127.

Mapel, W. J., and Sandberg, C. A., 1968, Devonian paleotectonics in east-central Idaho and southwestern Montana, in Geological Survey research 1968: U.S. Geol. Survey Prof. Paper 600-D, p. D115-D125.

Maughan, E. K., and Roberts, A. E., 1967, Big Snowy and Amsden groups and the Mississippian-Pennsylvanian boundary in Montana: U.S. Geol. Survey Prof. Paper 554-B, 27 p.

Peterson, J. A., 1972, Jurassic system, in Geologic Atlas of the Rocky Mountain Region: Denver, Rocky Mtn. Assoc. Geologists, p. 177-189.

Petkewich, R. M., 1972, Tertiary geology and paleontology of the Beaverhead East area, southwestern Montana: Montana Univ., Missoula, Ph.D. dissert., 365 p.

Powers, M. C., 1953, A new roundness scale for sedimentary particles: Jour. Sed. Petrology, v. 23, p. 117-119.

Richards, R. W., and Pardee, J. T., 1925, The Melrose phosphate field, Montana: U.S. Geol. Survey Bull. 780-A, p. A25-A32.

Roberts, A. E., 1966, Stratigraphy of Madison Group near Livingston, Montana, and discussion of karst and solution breccia features: U.S. Geol. Survey Prof. Paper 526-B, $23 \mathrm{p}$.

Robinson, G. D., 1963, Geology of the Three Forks quadrangle, Montana: U.S. Geol. Survey Prof. Paper 370, $143 \mathrm{p}$.

Ryder, R. T., and Ames, H. T., 1970, Palynology and age of Beaverhead Formation and their paleotectonic implications in Lima region, Montana-Idaho: Am. Assoc. Petroleum Geologists Bull., v. 54, p. 1155-1171.

Ryder, R. T., and Scholten, Robert, 1973, Syntectonic conglomerates in southwestern Montana-their nature, origin, and tectonic significance: Geol. Soc. America Bull., v. 84, p. $773-796$.

Sandberg, C. A., 1962, Stratigraphic section of type Three Forks and Jefferson formations at Logan, Montana, in The Devonian system of Montana and adjacent areas-a symposium: Billings Geol. Soc. 13th Ann. Field Conf. Guidebook, p. 47-50.

1965, Nomenclature and correlation of lithologic subdivisions of the Jefferson and Three Forks formations of southern Montana and northern Wyoming: U.S. Geol. Survey Bull. 1194-N, 18 p.

Sandberg, C. A., and Klapper, G., 1967, Stratigraphy, age, and paleotectonic significance of the Cottonwood Canyon Member of the Madison Limestone in Wyoming and Montana: U.S. Geol. Survey Bull. 1251-B, p. B1-B70.

Sandberg, C. A., and Mapel, W. J., 1967, Devonian of the northern Rocky Mountains and plains, in Oswald, D. H., ed., International symposium on the Devonian System: Calgary, Alberta Soc. Petroleum Geologists, v. 1, p. 843-877. 
Sando, W. J., and Dutro, J. T., Jr., 1960, Stratigraphy and coral zonation of the Madison Group and Brazer Dolomite in northeastern Utah, western Wyoming, and southwestern Montana, in Overthrust belt of southwestern Wyoming and adjacent areas: Wyoming Geol. Assoc. 15th Ann. Field Conf. Guidebook, p. 117-126.

Scholten, Robert, 1957, Paleozoic evolution of the geosynclinal margin north of the Snake River Plain: Geol. Soc. America Bull., v. 68, p. 151-170.

-1960 , Sedimentation and tectonism in the thrust belt of southwestern Montana and east-central Idaho, in Overthrust belt of southwestern Wyoming and adjacent areas: Wyoming Geol. Assoc. 15th Ann. Field Conf. Guidebook, p. 73-83.

1967, Structural framework and oil potential of extreme southwestern Montana, in West Yellowstone-Earthquake area: Billings Geol. Soc. 11th Ann. Field Conf. Guidebook, p. 7-19.

Scholten, Robert, and Hait, M. H., Jr., 1962, Devonian system from shelf edge to geosyncline, southwestern Montana-Central Idaho, in Devonian system of Montana and adjacent areas-a symposium: Billings Geol. Soc. 13th Ann. Field conf. Guidebook, p. 13-22.

Scholten, Robert, Keenmon, K. A., and Kupsch, W. O., 1955, Geology of the Lima region, southwestern Montana and adjacent Idaho: Geol. Soc. America Bull., v. 66, p. 345-404.

Scott, H. W., 1935, Some Carboniferous stratigraphy in Montana and northwestern Wyoming: Jour. Geology, v. 43, p. 1011-1032.

Sloss, L. L., 1954, Lemhi arch, a mid-Paleozoic positive element in south-central Idaho: Geol. Soc. America Bull., v. 65, p. 365-368.

Sloss, L. L., and Hamblin, R. H., 1942, Stratigraphy and insoluble residues of Madison Group (Mississippian) of Montana: Am. Assoc. Petroleum Geologists Bull., v. 26, p. 305-335.

Sloss, L. L., and Moritz, C. A., 1951, Paleozoic stratigraphy of southwestern Montana: Am. Assoc. Petroleum Geologists Bull., v. 35, p. 2135-2169.

Tysdal, R. G., 1966, Geology of a part of the north end of the Gallatin Range, Gallatin County, Montana: Montana State Univ., Bozeman M.S. thesis, 95 p. 1970, Geology of the northern end of the Ruby Range, southwestern Montana: U.S. Geol. Survey open-file report. 1976, Geologic map of the northern part of the Ruby Range, Montana: U.S. Geol. Survey Misc. Inv. Map. I-951 (in press).

Wier, K. W., 1965, Preliminary geologic map of the Black Butte iron deposit, Madison County, Montana: U.S. Geol. Survey open-file report.

Wilson, M. D., 1970, Upper Cretaceous-Paleocene synorogenic conglomerate of southwestern Montana: Am. Assoc. Petroleum Geologists Bull., v. 54, p. 1843-1867.

Witkind, I. J., 1969, Geology of the Tepee Creek quadrangle, Montana-Wyoming: U.S. Geol. Survey Prof. Paper 609, 101 p. 
Contributions to

Stratigraphy,

1976

GE O L O G I C A L S U R V E Y B U L L E T I N 1405

This volume was published as separate chapters $A-I$ 


\section{UNITED STATES DEPARTMENT OF THE INTERIOR}

THOMAS S. KLEPPE, Secretary

\section{GEOLOGICAL SURVEY}

V. E. McKelvey, Director

For sale by the Superintendent of Documents, U. S. Government Printing Office Washington, D. C. 20402 


\section{CONTENTS}

[Letters designate the chapters]

(A) Changes in stratigraphic nomenclature by the U.S. Geological Survey, 1974, by George V. Cohee and Wilna B. Wright.

(B) A Summary of Tertiary volcanic stratigraphy of the southwestern, high plateaus and adjacent Great Basin, Utah, by Peter D. Rowley, John J. Anderson, and Paul L. Williams.

(C) Revision of the lower part of the Tertiary system in the central and western Uinta Basin, Utah, by Thomas D. Fouch.

(D) Stratigraphy of the layered gabbroic Dufek intrusion, Antarctica, by Arthur B. Ford.

(E) McGowan Creek Formation, new name for lower Mississippian flysch sequence in east-central Idaho, by Charles A. Sandberg.

(F) The Buffalo Peaks andesite of central Colorado, by George F. Sanders, Jr., Glenn R. Scott, and Charles W. Naeser.

(G) Upper Cambrian Orr Formation: Its subdivisions and correlatives in western Utah, by Lehi F. Hintze and Allison R. Palmer.

(H) Silurian nomenclature and correlations in southwest Virginia and northeast Tennessee, by Ralph L. Miller.

(I) Paleozoic and Mesozoic stratigraphy of the northern part of the Ruby Range, southwestern Montana, by Russell G. Tysdal. 






ว 


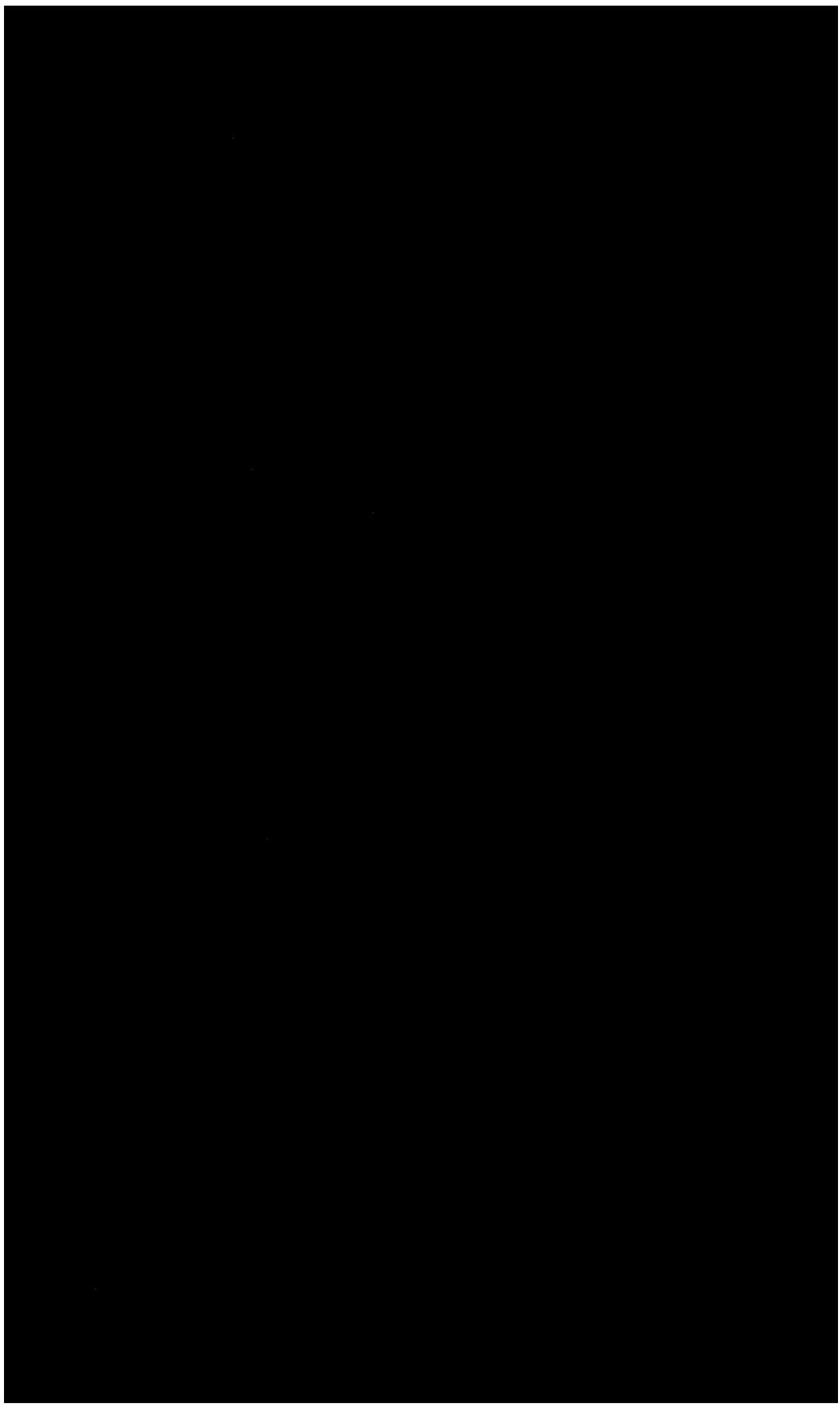




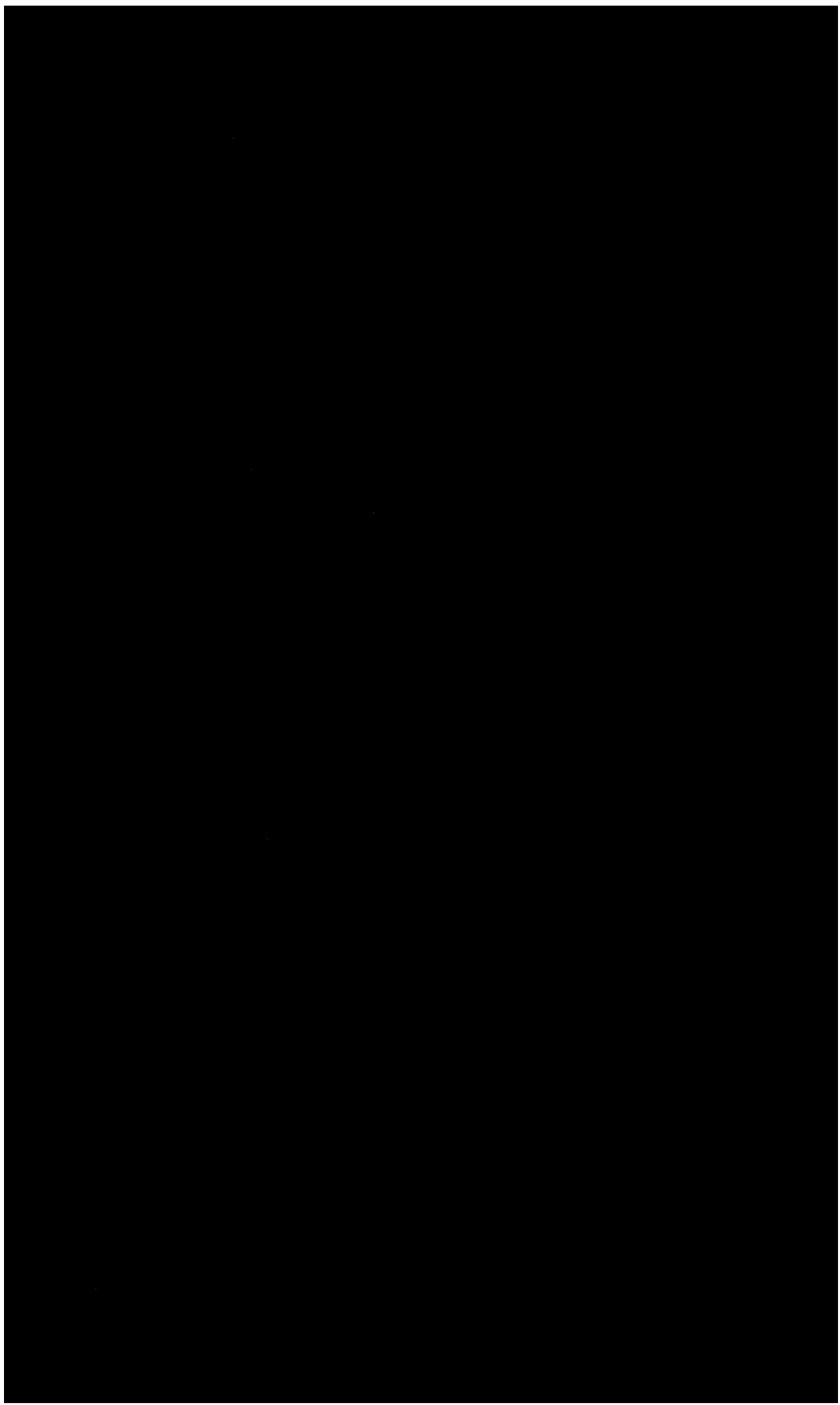

